\title{
Features of functioning of the russian pork market in the context of the pandemic and prospects for its development
}

\author{
Ekaterina Nifontova* \\ Russian State Agrarian University - Moscow Timiryazev Agricultural Academy, 127550 Moscow, \\ Russia
}

\begin{abstract}
Within the framework of this scientific article, the development of the domestic pork market is assessed at the present stage of development of the national economy. The trends of recent years in the framework of the functioning of the pork market in the structure of the meat and meat products market of the Russian Federation are revealed. The impact of the pandemic and quarantine measures on the development of the pork market in the first half of 2020 is analyzed. The assessment of changes in pork prices during the pre-quarantine and quarantine periods is carried out, as well as the factors of influence in this dynamics are identified. The analysis of the forecast dynamics of pork production for 2020 and 2021 is carried out. The features of the development of this market at the present stage are determined, and the assessment of this development of this market in the medium term is carried out.
\end{abstract}

\section{Introduction}

At the present stage of development of the world economy as a whole and the national economy in particular, an important role in the system of ensuring the proper level of development of the country is played by maintaining an effective level of food security of the state in the long-term time period.

The dynamics of the development of the food market situation regarding the internal security and price availability of key types of commodity products form a problem in the context of a systematic analysis of changes in the market of food group products.

Especially important in this issue is the monitoring and analysis of changes in prices for food products that have a high level of demand from the consumer in the context of the formation of the basic food basket. One of these products is pig meat - this product is fundamental in the system of forming the food basket of the population of the Russian Federation.

The coronavirus pandemic that began in the world in early 2020, as well as the subsequent quarantine restrictions in the Russian Federation have significantly influenced the level of economic development, business activity and consumer demand and generate

*Corresponding author: eanifontova@mail.ru 
the need for a comprehensive analysis in the field of pork market development regarding these factors of influence, which determines the relevance of the topic of this scientific article.

\section{Materials and methods}

The research object of this scientific article is the pork market in the context of a pandemic and quarantine measures introduced in the first half of 2020. The key methods for processing statistical information were vertical and horizontal analysis, as well as the principle of comparison.

In the context of achieving completeness of disclosure of the research topics, the following methods were used in the framework of working with the materials of the work: methods of the empirical study (comparison, observation and measurement), methods of theoretical knowledge (formalization), as well as generally accepted research methods (analysis, synthesis, analogy, and systematic approach).

The information base of the work was made up of scientific works of domestic scientists-economists $[1,2,3,4]$, as well as analytical and statistical information on the pork market development $[5,6,7,8,9,10,11]$.

\section{Results and discussion}

Meat and meat products are the most important food products in most countries of the world. The demand for meat products in the world is growing in accordance with the increase in the level of development of countries and the solvency of the population, and the growth of the world's population also has an impact [3].

Pig breeding is one of the most important branches of animal husbandry to ensure food security in Russia. Currently, there is a fairly steady increase in pork production in farms of all forms of ownership [2].

Pork belongs to the food category of products of social significance. An important infrastructure component of the production process and bringing this product to the end user is the market environment. The degree of satisfaction of the consumer demand, and, consequently, the quality of life of the country's citizens depends on how effectively and rationally it (the environment) functions, on what basic principles and approaches the system of organization and management of this sphere of the national economy is based [1].

One of the significant factors that ensure the development of pig breeding is the sale of pork, i.e. it is not enough to produce products - you need to sell them. Russian pig-breeding enterprises operate in a rigid system of the world market and therefore must master the science of food market management and be able to protect their interests [4].

In the context of the subject disclosure of this scientific article subject, we will disclose and analyze the key factors affecting the efficiency of pork production, for which we will use the diagram below (figure 1), which clearly shows these indicators. 


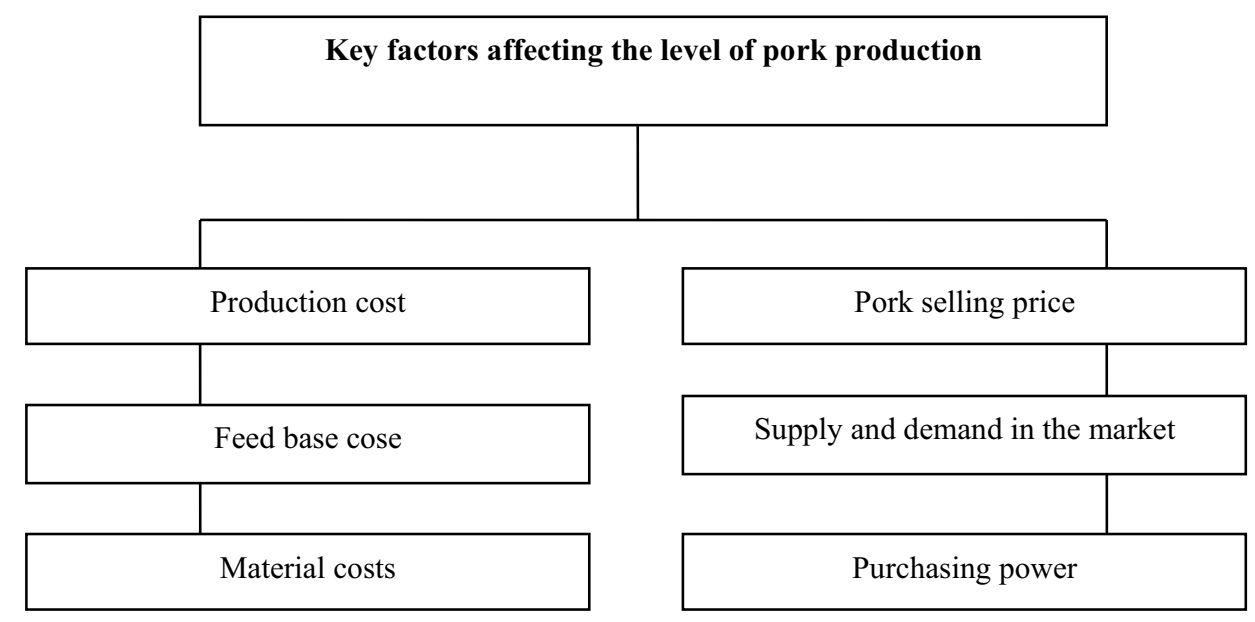

Fig.1. Key factors affecting the level of pork production [4]

As can be seen from the above diagram, in the system of the pork market development in the Russian Federation at the present stage, the effectiveness and features of its functioning are directly affected by two key factors:

- production cost - this factor directly depends on the cost of key agricultural crops, labor costs, and feed delivery costs. This factor is also influenced by energy and water prices;

- $\quad$ sales price - this factor directly depends on the level of income of the population ( since more than $95 \%$ of pig production is sold on the domestic market [5]), consumer demand and consumer sentiment. In addition, it should be noted that prices for pig meat are directly related to the dynamics of prices for poultry meat [6-10].

It is necessary to understand that these factors were significantly affected by the coronavirus pandemic and subsequent quarantine measures introduced in the Russian Federation in the first half of 2020, which generates the need for a more detailed analysis of the development of the pork market at the current stage of development of the state national economy.

Let's analyze the dynamics of pork production in the structure of the meat and meat products market of the Russian Federation for the period from 2016 to 2021 (forecast), inclusive, using the diagram below (figure 2) 


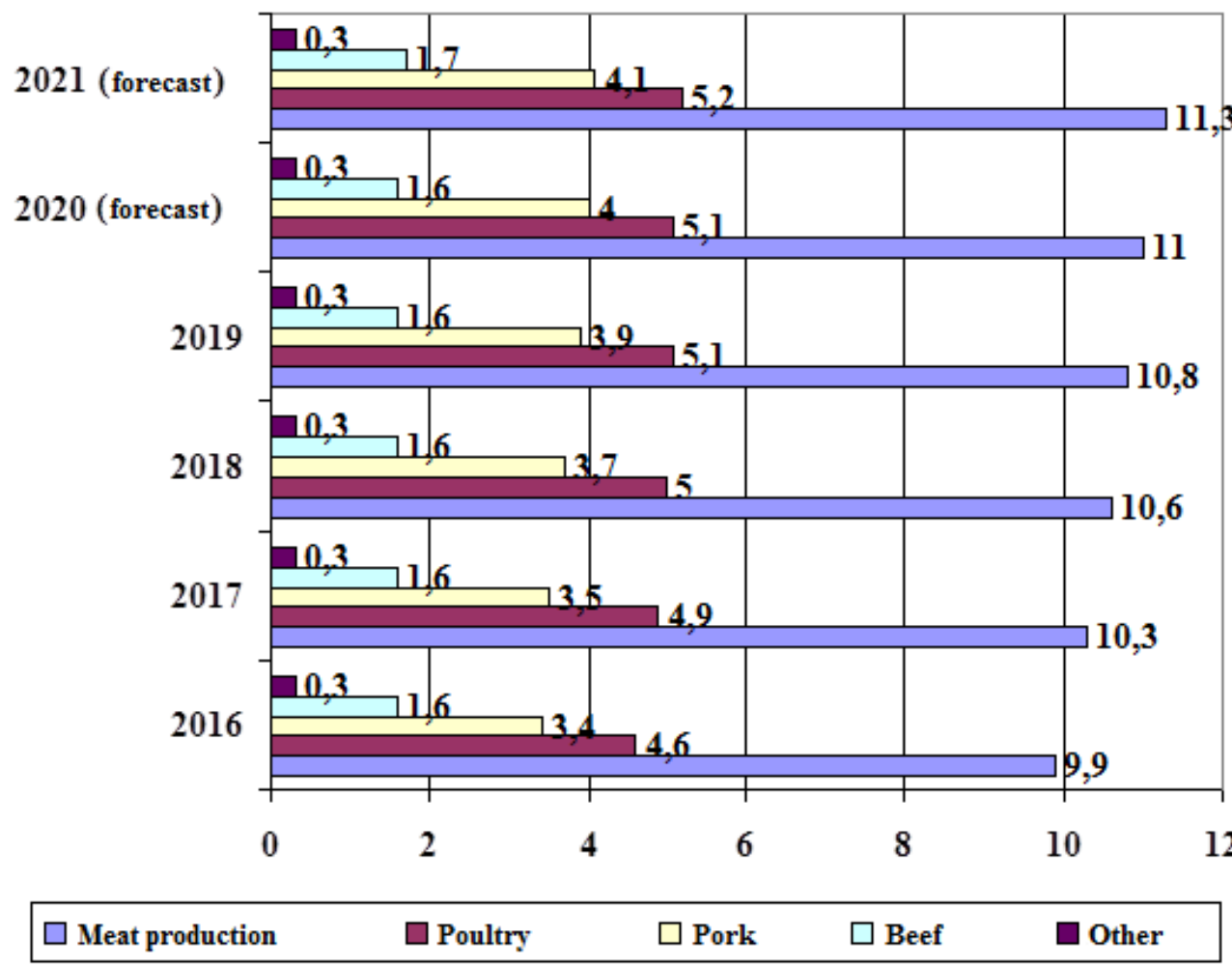

Fig.2. Pork production in the structure of the Russian meat and meat products market (million tons) $[5]$

In accordance with the diagram above, the following conclusions can be drawn:

- $\quad$ pork production for the analyzed time period will grow by $20.6 \%$ or 0.7 million tons from 3.4 million tons in 2016 to 4.1 million tons by the end of 2021, respectively; for comparison, total meat production will grow by $14.1 \%$, and poultry production will grow by $13 \%$, respectively;

- the share of pork in total meat production in the Russian Federation over the analyzed time period will increase by 1.9 percentage points, from $34.3 \%$ in 2016 to $36.2 \%$ by the end of 2021. At the same time, the share of poultry in total meat production in the Russian Federation over the same period will decrease by 0.4 percentage points from $46.4 \%$ in 2016 to $46 \%$ by the end of 2021 ;

- the average annual growth rate of pork production over the analyzed time period will be $3.8 \%$, while the average annual growth rate of meat production will be $2.7 \%$, and the average annual growth rate of poultry production will be $2.5 \%$;

- at the same time, it should be noted that if in 2018 and 2019 the annual growth rate of pork production was $5.5 \%$, in 2020 it is expected to fall to $2.6 \%$, and in 2021 to $2.5 \%$, respectively.

In general, it can be determined that, despite the coronavirus pandemic, as well as the introduced quarantine measures, pork production will continue to show growth in 2020 and 2021 , but the growth rate is expected to decrease in physical terms.

As part of the substantive disclosure of the problems of this research article, we will analyze the prices of pig meat (live weight) for January-May 2019 and January-May 2020, 
in order to determine the price correction due to the coronavirus pandemic and the quarantine restrictions imposed.

To do this, we will use the diagram below (figure 3), which clearly shows the dynamics of these indicators for the analyzed time period.

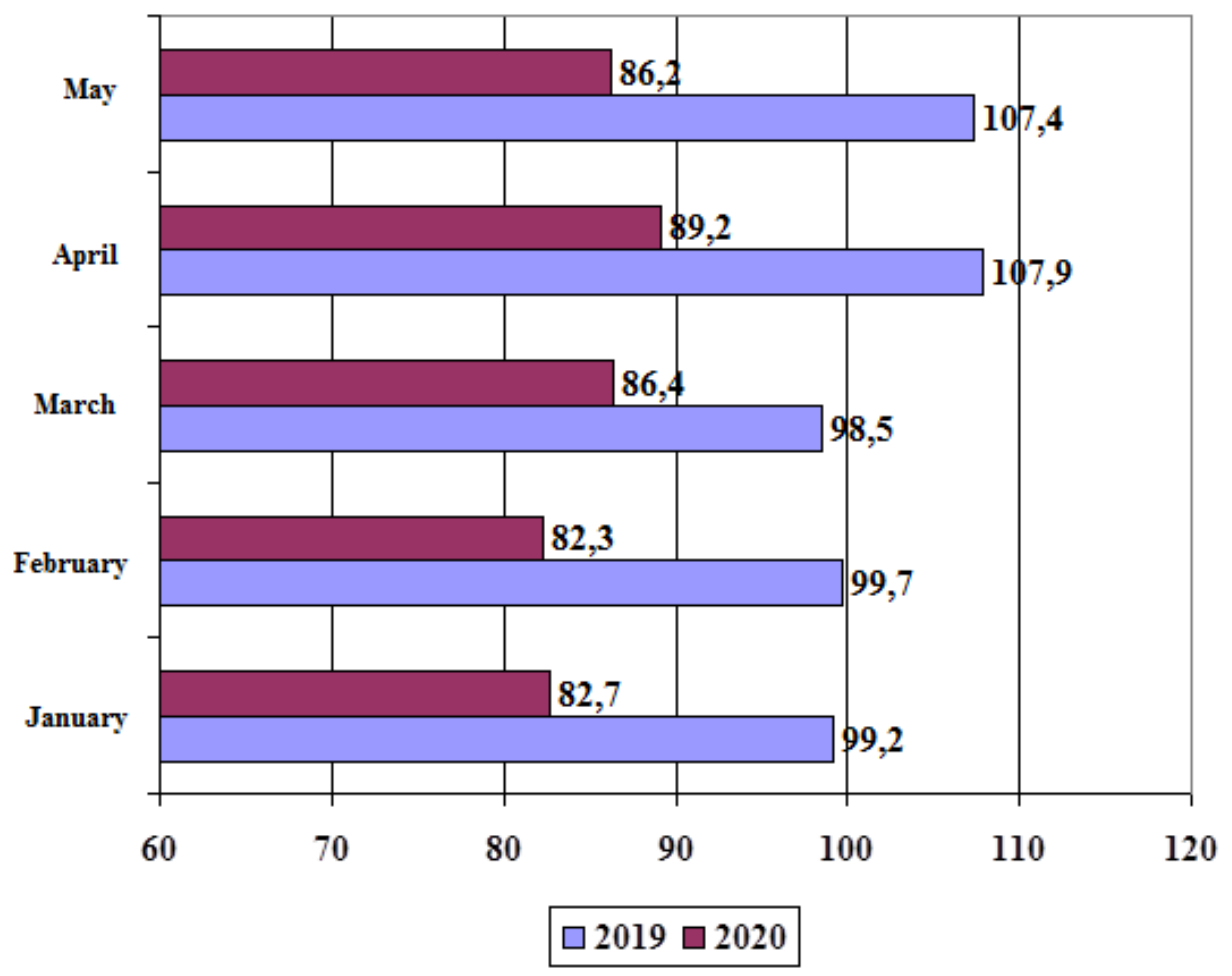

Fig.3. Dynamics of pork prices (live weight) January-May 2019 to January-May 2020 (rubles/kg) [6-10]

As it can be see from the above diagram the following changes and transformations in the dynamics of pork prices occurred during the analyzed time period:

- $\quad$ prices for live pork in January-May 2019 increased by $8.3 \%$ or 8.2 rubles per kilogram, from 99.2 rubles per kilogram in January to 107.4 rubles per kilogram in May;

- $\quad$ prices for live pork in January-May 2020 increased by $4.2 \%$ or 3.5 rubles per kilogram, from 82.7 rubles per kilogram in January to 86.2 rubles per kilogram in May;

- generally, it should be noted that prices for pork (live weight) in January-May 2020 were significantly lower than prices for the same time period in 2019. On average, prices for pork (live weight) in 2020 were lower by $16.7 \%$ or 17.2 rubles per kilogram.

In many ways, this price reduction in 2020 compared to 2019 was due to the following factors:

- the decline in consumer demand and purchasing power of the population of the Russian Federation due to quarantine measures;

- $\quad$ reduced prices for poultry meat, which led to the need to reduce prices for pig meat in order to maintain the proper level of sales of this type of product.

Similarly, we will analyze prices for pig meat (slaughter weight) for January-May 2019 and January-May 2020 (Figure 4). 


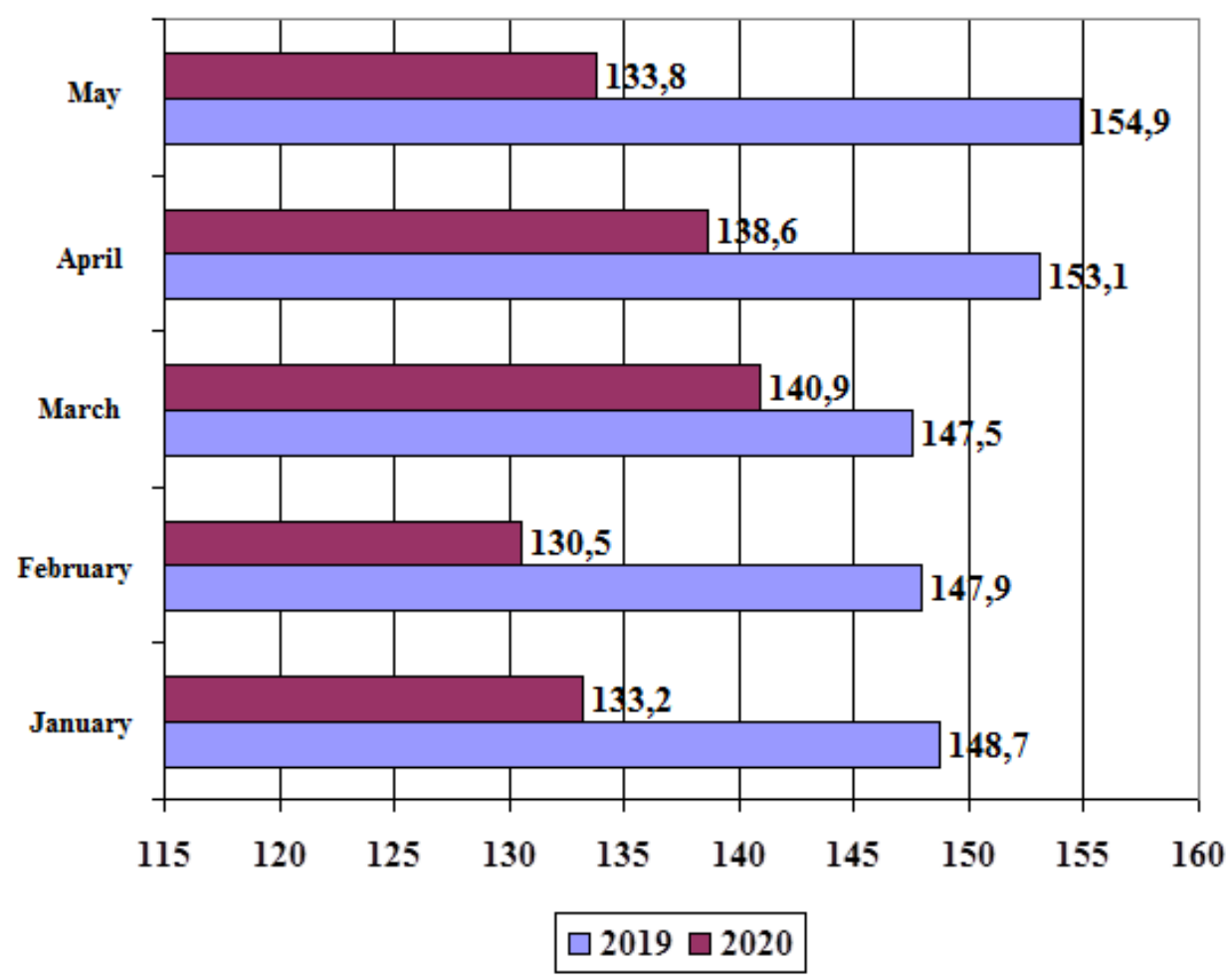

Fig.4. Dynamics of pork prices (slaughter weight) January-May 2019 to January-May 2020 (rubles $/ \mathrm{kg}$ ) [6-10]

In accordance with the above diagram, the following changes and transformations occurred in the dynamics of pork prices over the analyzed time period:

- $\quad$ prices for slaughter-weight pork in January-May 2019 increased by $4.2 \%$ or 6.2 rubles per kilogram, from 148.7 rubles per kilogram in January to 154.9 rubles per kilogram in May;

- $\quad$ prices for slaughter-weight pork in January-May 2020 increased by $0.5 \%$ or 0.6 rubles per kilogram, from 133.2 rubles per kilogram in January to 133.8 rubles per kilogram in May;

- generally, it should be noted that prices for pork (slaughter weight) in JanuaryMay 2020 were significantly lower than prices for the same time period in 2019. On average, prices for pork (slaughter weight) in 2020 were lower by $10 \%$ or 15 rubles per kilogram.

This decrease in prices in 2020 compared to 2019 was due to the following factors (similar to the dynamics of prices for live weight pork):

- the decline in consumer demand and purchasing power of the population of the Russian Federation due to quarantine measures;

- reduced prices for poultry meat, which led to the need to reduce prices for pig meat in order to maintain the proper level of sales of this type of product. 


\section{Conclusion}

As a result of this research article, we can draw the following conclusions:

1. Pig meat is one of the key products of the domestic meat industry, which is caused by an increase in the share of this product in the total production of meat and meat products (up to $36.2 \%$ in 2021 of the total volume).

2. Despite the coronavirus pandemic and quarantine restrictions imposed in the Russian Federation, the pork market continues to show growth in physical terms. So it is expected that in 2020, the volume of pork production will exceed the volume of production in 2019 by $2.6 \%$, and in 2021 by $2.5 \%$, respectively.

3. At the same time, it should be noted that in the first half of 2020, prices for pork in both live and slaughter weight were slightly lower than the same prices in the first half of 2019. This pricing policy indicates that pork meat producers optimize sales of products relative to consumer demand and the purchasing power of the population.

4. Potentially in the coming years the growth of pork production will continue, due to the fact that this product is part of the primary niche of the food basket of most of the population, the deepening economic crisis in the country and the fall in real incomes can prevent this dynamics.

\section{References}

1. I.P. Bogomolova, A.V. Kotarev, A.O. Kotareva, Bulletin of the Kursk State Agricultural Academy, 1 (2019) URL: https://cyberleninka.ru/article/n/otsenkasovremennogo-sostoyaniya-i-perspektiv-razvitiya-otechestvennogo-rynka-myasa-imyasoproduktov

2. V.M. Zimnyakov, Bulletin of the All-Russia Research and Development Institute of Livestock Breeding Mechanization. 2(34) (2019) URL: https://cyberleninka.ru/article/n/proizvodstvo-svininy-v-rossii

3. E.L. Zolotareva, Bulletin of the Kursk State Agricultural Academy, 3, (2018) URL: https://cyberleninka.ru/article/n/mirovoy-rynok-myasa-sovremennye-tendentsiirazvitiya-i-perspektivy-uchastiya-rossii

4. L.M. Tsoi. Bulletin of the All-Russia Research and Development Institute of Livestock Breeding Mechanization, 1(29) (2018) URL: https://cyberleninka.ru/article/n/perspektivy-razvitiya-svinovodstva-v-rossii

5. Meat market in Russia: results of 2019 and prospects (FSBI "Agricultural Analysis Center") URL: https://specagro.ru/news/202003/rynok-myasa-v-rossii-itogi-2019-g-iperspektivy

6. Monthly review of the meat market in January 2020 (FSBI "Agricultural Analysis Center") URL: https://www.specagro.ru/analytics/202002/ezhemesyachnyy-obzormyasnogo-rynka-za-yanvar-2020-goda

7. Monthly review of the pork and poultry meat market in February 2020 (FSBI "Agricultural Analysis Center"). URL: https://www.specagro.ru/analytics/202003/ezhemesyachnyy-obzor-rynka-svininy-imyasa-pticy-za-fevral

8. Monthly review of the pork and poultry meat market in March 2020 (FSBI "Agricultural Analysis Center"). URL: https://specagro.ru/analytics/202004/ezhemesyachnyy-obzor-rynka-svininy-i-myasapticy-za-mart-2020-goda 
9. Monthly review of the pork and poultry meat market in April 2020 (FSBI "Agricultural Analysis Center"). URL: https://www.specagro.ru/analytics/202005/ezhemesyachnyyobzor-rynka-svininy-i-myasa-pticy-za-aprel-2020

10. Monthly review of the pork and poultry meat market in May 2020 (FSBI "Agricultural Analysis Center"). URL: https://www.specagro.ru/sites/default/files/202006/obzor_myaso_21_nedelya_.pdf

11. E.A. Nifontova, Models of market equilibrium in the agricultural sector of the economy in modern conditions, Materials of the International Scientific Conference of Young Scientists and Specialists dedicated to the 150th anniversary of A.V. Leontovich. Collected papers, 339-343 (2019) 